\title{
PENGARUH PENYULUHAN TERHADAP PENGETAHUAN, SIKAP, DAN TINDAKAN MAHASISWA TERKAIT PENGGUNAANALAT PELINDUNG TELINGA DARI BAHAYA KEBISINGAN SAAT MENGGERINDA
}

\section{RUANG PENGELASAN UNIVERSITAS NEGERI MALANG}

\author{
Firda Baihaq \\ Marji \\ Erianto Fanani \\ Universitas Negeri Malang \\ e-mail: firdabaihaq1995@gmail.com
}

\begin{abstract}
The noise level from grinding activities in Welding Laboratory State University of Malang is $98 \mathrm{~dB}$ exceeds the Threshold Limit Value (TLV) is $85 \mathrm{~dB}$. Students are not always use provided ear protective equipment which can cause occupational diseases such as Noise Induced Hearing Loss. According to the World Health Organization, counseling is one of health promotion technique to prevent disease and provide health information. The variables which measured are knowledge, attitude, and practice in using Ear Protective Equipment. This research use one group pretest posttest method design with 17 students at Welding Laboratory State University of Malang. Counseling was held by presentation and handout materials which followed with lecture and discussion. Data analys with Wilcoxon Signed Ranks Test, showed that: the value of Z -3.644 and Asymp. Sig. (2-tailed) of 0.000 at knowledge variable, the value of Z -3.368 and Asymp. Sig. (2-tailde) 0.001 on attitude variable, and the value of $Z-3873$ and Asymp. Sig. (2-tailed) 0.001 on practice variable is smaller than 0.05 . The conclusion of hypothesis is that there is any effect of counseling to student knowledge, attitude, and practice in using Ear Protective Equipment from grinding noise hazard at Welding Laboratory State University of Malang.
\end{abstract}

Keywords: counseling, knowledge, attitude, practice, ear protective equipment

\begin{abstract}
Abstrak: Kebisingan yang ditimbulkan dari kegiatan menggerinda di Ruang Pengelasan Universitas Negeri Malang adalah $98 \mathrm{~dB}$ melebihi Nilai Ambang Batas (NAB) yaitu $85 \mathrm{~dB}$. Mahasiswa saat menggerinda tidak selalu menggunakan Alat Pelindung Telinga sehingga dapat menyebabkan penyakit akibat kerja berupa Noise Induced Hearing Loss. Menurut World Health Organization, penyuluhan merupakan salah satu cara promosi kesehatan untuk mencegah penyakit dan bertujuan memberikan informasi kesehatan. Variabel yang diukur dalam penelitian ini yaitu pengetahuan, sikap, dan tindakan mahasiswa terkait penggunaan Alat Pelindung Telinga. Metode penelitian ini menggunakan desain penelitian one group pretest posttest terhadap 17 mahasiswa di Ruang Pengelasan Universitas Negeri Malang. Penyuluhan dilakukan dengan media presentasi dan handout materi serta metode ceramah dan tanya jawab. Analisis data menggunakan Wilcoxon Signed Ranks Test menunjukkan hasil: nilai Z -3,644 dan Asymp. Sig. (2-tailed) 0,000 pada variabel pengetahuan, nilai Z -3,368 dan Asymp. Sig. (2-tailed) 0,001 pada variabel sikap, serta nilai Z -3873 dan Asymp. Sig. (2-tailed) 0,001 pada variabel tindakan mahasiswa berarti lebih kecil daripada 0,05. Kesimpulan dari pengujian hipotesis tersebut adalah terdapat pengaruh penyuluhan terhadap pengetahuan, sikap, dan tindakan mahasiswa terkait penggunaan Alat Pelindung Telinga dari bahaya kebisingan saat menggerinda di Ruang Pengelasan Universitas Negeri Malang.
\end{abstract}

Kata kunci: penyuluhan, pengetahuan, sikap, tindakan, alat pelindung telinga 
Las yang merupakan kata dasar pengelasan berarti penyambungan besi dan sebagainya dengan cara membakar (Kamus Besar Bahasa Indonesia, 2002: 642). Terdapat kegiatan yang selalu dilakukan dalam proses pengelasan. Kegiatan tersebut adalah menggerinda. Kegiatan menggerinda dapat dilakukan pada saat persiapan, repair (menata ulang), maupun finishing (penyelesaian). Tujuan menggerinda diantaranya memotong benda kerja, membentuk benda kerja, dan menciptakan benda kerja sesuai kebutuhan.

Peraturan Menteri Tenaga Kerja dan Transmigrasi Republik Indonesia Nomor 13 Tahun 2011 tentang Nilai Ambang Batas Faktor Fisika dan Faktor Kimia di Tempat Kerja menjelaskan bahwa kebisingan adalah semua suara yang tidak dikehendaki yang bersumber dari alatalat proses produksi dan/atau alat-alat kerja yang pada tingkat

tertentu dapat menimbulkan kebisingan. Peneliti melakukan pengukuran kebisingan pada saat menempuh Mata Kuliah Praktikum Keselamatan dan Kesehatan Kerja (K3) di Ruang Pengelasan Universitas Negeri Malang terhadap mahasiswa yang sedang menggerinda di Ruang

Pengelasan Universitas Negeri Malang. Peneliti mengukur kebisingan dengan menggunakan alat ukur environmental meter. Hasil yang diperoleh dari pengukuran kebisingan tersebut adalah $98 \mathrm{~dB}$. Nilai Ambang Batas (NAB) kebisingan yang ditetapkan oleh Amerika Serikat, Inggris, Jerman Barat, Yugoslavia, dan Jepang adalah 90 dB (Marji, 2013:6). Sedangkan menurut Peraturan Menteri Tenaga Kerja dan Transmigrasi Republik Indonesia Nomor 13 Tahun 2011 tentang Nilai Ambang Batas Faktor
Fisika dan Faktor Kimia di Tempat Kerja menegaskan bahwa NAB

Kebisingan adalah 85 dB. Kesimpulannya adalah kegiatan menggerinda yang dilakukan mahasiswa di Ruang Pengelasan

Universitas Negeri Malang menimbulkan kebisingan yang melebihi NAB.

Kebisingan menyebabkan berbagai gangguan, seperti gangguan fisiologis, gangguan psikologis, gangguan komunikasi, dan ketulian (Christy, 2010:6). Salah satu gangguan akibat kebisingan adalah Noise Induced Hearing Loss (NIHL). Menurut The National Institute of Occupational Safety and Health (2016), Noise Induced Hearing Loss (NIHL) adalah sebuah penyakit akibat kerja berupa gangguan pendengaran atau ketulian akibat kebisingan. Pada tahun 2016, Centers for Disease Control and Prevention menerangkan bahwa $82 \%$ penyakit akibat kerja yang terjadi adalah ketulian akibat kerja. Insidensi NIHL di Selandia Baru sekitar 1077 sampai dengan 1537 kasus di tempat kerja (Laird, 2012:10). Penelitian yang dilakukan Prasetyo pada tahun 2015 terhadap pekerja Bengkel Las Purwareja

menyimpulkan $63,33 \%$ pekerja mengalami NIHL.

Salah satu upaya yang dapat dilakukan untuk menghindari bahaya kebisingan adalah menggunakan Alat Pelindung Telinga. Alat Pelindung Telinga merupakan salah satu Alat Pelindung Diri (APD) sebagaimana yang tercantum pada Peraturan Menteri Tenaga dan Transmigrasi Republik Indonesia Nomor 08 Tahun 2010 tentang Alat Pelindung Diri. Observasi yang dilakukan oleh peneliti terhadap mahasiswa yang menggerinda di Ruang Pengelasan Universitas Negeri Malang 
menunjukkan bahwa tidak semua mahasiswa selalu menggunakan Alat Pelindung Telinga yang telah disediakan, seperti earplug, earmuff, dan alat yang terintegrasi dengan Alat Pelindung Diri lain yaitu welding helmet.

\section{METODE}

Jenis penelitian yang digunakan adalah observasional crossectional dengan desain penelitian one group pretest posttest.

Populasi penelitian merupakan populasi infinite yaitu mahasiswa yang menggerinda di Ruang Pengelasan Universitas Negeri Malang. Sampel yang digunakan dalam penelitian adalah 17 mahasiswa yang menempuh matakuliah Praktikum Pengelasan di Ruang Pengelasan Universitas Negeri Malang pada Januari-Februari 2017.

\section{HASIL PENELITIAN}

\section{Variabel Pengetahuan Mahasiswa}

Gambar 1 Data Pretest Variabel Pengetahuan Mahasiswa

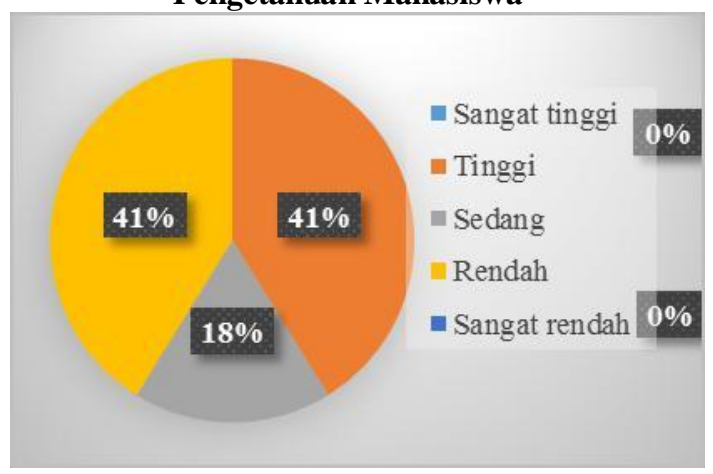

Hasil pretest yang dilakukan menunjukkan bahwa klasifikasi pengetahuan mahasiswa terkait penggunaan Alat Pelindung Telinga dari bahaya kebisingan saat menggerinda yaitu: (1) sebanyak 7 (41\%) mahasiswa memiliki pengetahuan tinggi, (2) sebanyak 3 (18\%) mahasiswa memiliki pengetahuan sedang, dan (3) sebanyak 7 (41\%) mahasiswa memiliki pengetahuan rendah.

Gambar 2 Data Poosttest Variabel Pengetahuan Mahasiswa

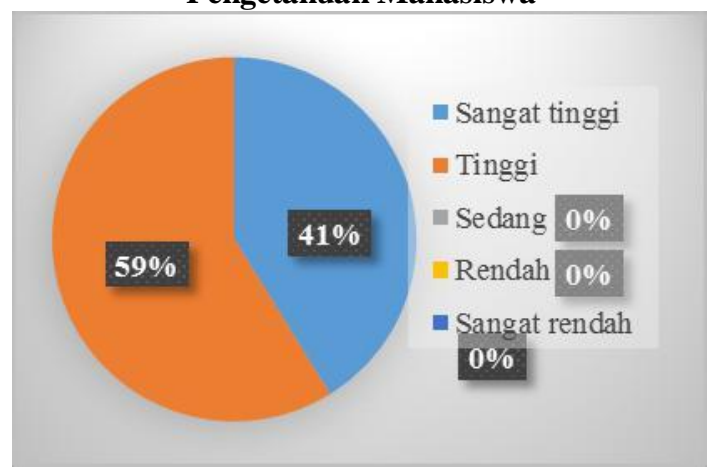

Intervensi berupa penyuluhan yang dilakukan kepada 17 mahasiswa menunjukkan hasil data posttest yaitu sebanyak $10 \quad(59 \%)$ mahasiswa memiliki pengetahuan tinggi dan 7 (41\%) mahasiswa memiliki pengetahuan sangat tinggi.

\section{Variabel Sikap Mahasiswa}

Distribusi data hasil pretest dan posttest dari kuesioner sikap yang telah diberikan pada 17 mahasiswa sebagai responden adalah sebagai berikut:

Gambar 3 Data Pretest Variabel Sikap Mahasiswa

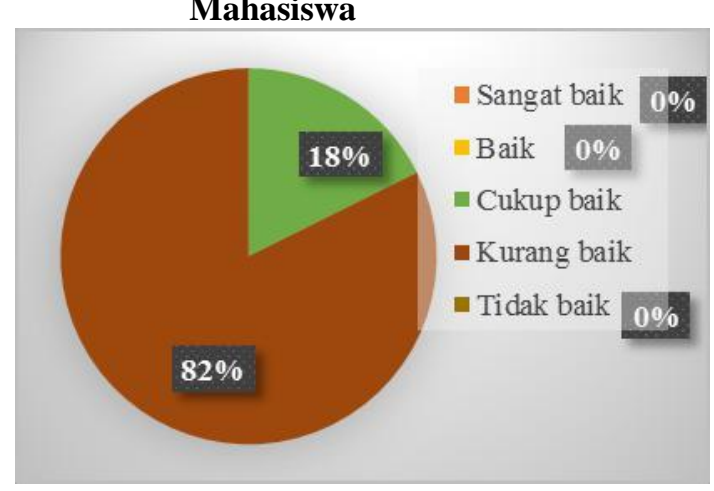

Pretest sikap yang diisi 17 mahasiswa menunjukkan data dengan tingkat sikap kurang baik sebanyak 14 (82\%) mahasiswa dan sebanyak 3 (18\%) mahasiswa memiliki sikap cukup baik. 


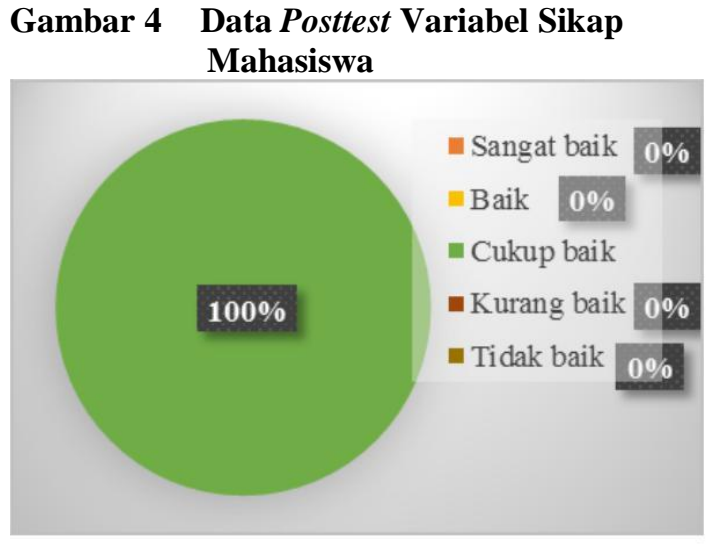

Penyuluhan dilakukan kepada 17 mahasiswa dan didapatkan hasil posttest yaitu 17 mahasiswa tersebut memiliki sikap cukup baik.

\section{Variabel Tindakan Mahasiswa}

Distribusi data hasil pretest dan posttest observasi tindakan yang telah diberikan pada 17 mahasiswa sebagai responden adalah sebagai berikut:

\section{Gambar 5 Data Pretest Variabel} Tindakan Mahasiswa

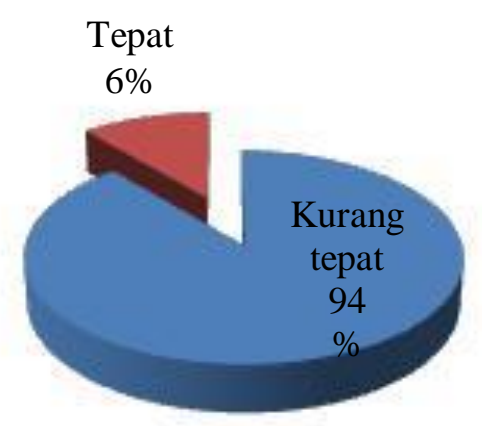

Gambar 5 dapat menjelaskan bahwa tindakan 16 mahasiswa pada saat pretest menunjukkan tindakan kurang tepat saat menggerinda. Tindakan yang dimaksud adalah tidak menggunakan Alat Pelindung Telinga. Hanya seorang mahasiswa menggunakan Alat Pelindung Telinga berupa Welding Helmet.

Setelah penyuluhan diberikan kepada 17 mahasiswa didapatkan data posttest sebagai berikut:
Gambar 6 Data Posttest Variabel Tindakan Mahasiswa

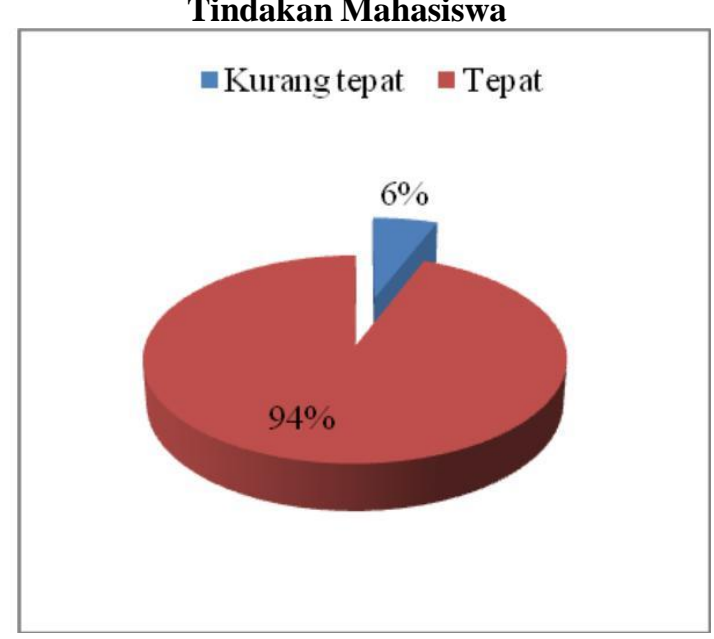

Intervensi berupa penyuluhan yang dilakukan dapat menunjukkan data posttest yakni sebanyak 16 (94\%) mahasiswa melakukan tindakan tepat yakni menggunakan Alat Pelindung Telinga saat menggerinda dan seorang lainnya (5\%) mahasiswa masih melakukan tindakan kurang tepat.

\section{Uji Normalitas}

Output uji normalitas variabel pengetahuan mahasiswa terkait penggunaan Alat Pelindung Telinga menunjukkan Shapiro-Wilk 0,028 dan 0,029 lebih kecil dari 0,05 yang artinya data tidak berdistribusi normal.

Output uji normalitas variabel sikap mahasiswa terkait penggunaan Alat Pelindung Telinga menunjukkan Shapiro-Wilk 0,001 dan 0,025 lebih kecil dari 0,05 yang artinya data tidak berdistribusi normal.

\section{Hasil Uji Hipotesis}

Penelitian ini memiliki 3 (tiga) hipotesis kerja sebagai berikut:

1. Perbedaan Pemahaman Pengetahuan Mahasiswa terkait Penggunaan Alat Pelindung Telinga dari Bahaya Kebisingan saat Menggerinda di Ruang 
Pengelasan Universitas

Negeri Malang Sebelum dan

Sesudah Penyuluhan.

Tabel 1 Hasil Wilcoxon Signed Ranks Test Variabel Pengetahuan Mahasiswa

\begin{tabular}{ll}
\hline & Posttest - Pretest \\
\hline$Z$ & $-3,644^{0}$ \\
\hline Asymp. Sig. (2-tailed) &, 000 \\
\hline
\end{tabular}

Output dari pretest dan posttest kuesioner variabel pengetahuan mahasiswa menunjukkan nilai Z yakni -3,644 dan Asymp. Sig. (2-tailed) yakni 0,000 lebih kecil dari pada 0,05 dan hipotesis kerja diterima. Kesimpulan dari hasil uji Wilcoxon Signed Ranks Test untuk variabel pengetahuan mahasiswa adalah terdapat pengaruh penyuluhan terhadap pengetahuan mahasiswa terkait penggunaan Alat Pelindung Telinga dari bahaya kebisingan saat menggerinda di Ruang Pengelasan Universitas Negeri Malang.

2. Perbedaan Sikap Mahasiswa terkait Penggunaan Alat Pelindung Telinga dari Bahaya Kebisingan saat Menggerinda di Ruang Pengelasan Universitas Negeri Malang Sebelum dan Sesudah Penyuluhan.

Tabel 2 Hasil Wilcoxon Signed Ranks Test Variabel Sikap Mahasiswa

\begin{tabular}{ll}
\hline & Posttest - Pretest \\
\hline $\mathrm{Z}$ & $-3.368^{\mathrm{D}}$ \\
\hline Asymp. Sig. (2-tailed) & .001 \\
\hline
\end{tabular}

Output dari pretest dan posttest kuesioner variabel sikap mahasiswa menunjukkan nilai $\mathrm{Z}$ yakni -3,368 dan Asymp. Sig. (2tailed) yakni 0,001 lebih kecil dari pada 0,05 dan hipotesis kerja diterima. Kesimpulan dari hasil uji Wilcoxon Signed Ranks Test untuk variabel sikap mahasiswa adalah terdapat pengaruh penyuluhan terhadap sikap mahasiswa terkait penggunaan Alat Pelindung Telinga dari bahaya kebisingan saat menggerinda di Ruang Pengelasan Universitas Negeri Malang.

3. Perbedaan Tindakan Mahasiswa Menggunakan Alat Pelindung Telinga dari Bahaya Kebisingan saat Menggerinda di Ruang Pengelasan Universitas Negeri Malang Sebelum dan Sesudah Penyuluhan.

Tabel 3 Hasil Wilcoxon Signed Ranks Test Variabel Tindakan Mahasiswa

\begin{tabular}{ll}
\hline & Posttest - Pretest \\
\hline$Z$ & $-3,873^{\mathrm{D}}$ \\
\hline Asymp. Sig. (2-tailed) &, 000 \\
\hline
\end{tabular}

Output dari pretest dan posttest tindakan mahasiswa menunjukkan nilai $Z$ yakni -3,873 dan Asymp. Sig. (2-tailed) yakni 0,000 lebih kecil dari pada 0,05 dan hipotesis kerja diterima. Kesimpulan dari hasil uji Wilcoxon Signed Ranks

Test untuk variabel tindakan mahasiswa adalah terdapat pengaruh penyuluhan terhadap tindakan mahasiswa terkait penggunaan Alat Pelindung Telinga dari bahaya kebisingan saat menggerinda di Ruang Pengelasan Universitas Negeri Malang.

\section{PEMBAHASAN \\ Deskripsi Variabel Pengetahuan Mahasiswa}

Gambar 1 data pretest yang dilakukan menunjukkan bahwa klasifikasi pengetahuan mahasiswa terkait penggunaan Alat Pelindung Telinga dari bahaya kebisingan saat menggerinda yaitu: (1) sebanyak 7 (tujuh) atau $41 \%$ mahasiswa memiliki pengetahuan tinggi, (2) sebanyak 3 (tiga) atau $18 \%$ mahasiswa memiliki pengetahuan sedang, dan (3) 
sebanyak 7 (tujuh) atau $41 \%$ mahasiswa memiliki pengetahuan rendah. Intervensi berupa penyuluhan dilakukan kepada 17 mahasiswa. Hasil data posttest didapatkan sebanyak 10 atau 59\% mahasiswa memiliki pengetahuan tinggi dan 7 (tujuh) atau $41 \%$ mahasiswa memiliki pengetahuan sangat tinggi.

World Health Organization menerangkan bahwa salah satu bentuk promosi kesehatan untuk mencegah penyakit akibat kerja dalam hal ini adalah Noise Induced Hearing Loss yaitu penyuluhan (counceling) sebagai salah satu cara pemberian informasi yang sejelas-

jelasnya sehingga masyarakat memiliki pemahaman dan pengetahuan (Afrianto, 2013:51).

Pengetahuan mahasiswa terkait penggunaan Alat Pelindung Telinga merupakan salah satu variabel yang diukur dalam penelitian ini. Adapun materi yang disampaikan dalam penyuluhan diantaranya: (a) dasar hukum, (b) kebisingan, (c) Noise Induced Hearing Loss, dan (d) Alat Pelindung Telinga yang

digunakan saat menggerinda. Penelitian ini menunjukkan

bahwa penyuluhan sebagai salah satu cara dalam memberikan informasi kesehatan dapat memberi pemahaman terhadap pengetahuan mahasiswa terkait penggunaan Alat Pelindung

Telinga saat menggerinda.

Pengetahuan sangat penting dipahami sebagai indikator yang diukur dalam keberhasilan promosi kesehatan.

Selain itu, pengetahuan merupakan pemahaman awal mahasiswa untuk memiliki respon tertutup lainnya yaitu sikap.

Pengetahuan mahasiswa dapat dibedakan dari hasil pretest dan posttest kuesioner pengetahuan. Hal ini dapat menggambarkan bahwa sebelum penyuluhan dilakukan kepada mahasiswa, mereka memiliki pengetahuan yang rendah dikarenakan belum mendapatkan informasi kesehatan yang jelas. Data posttest yang diambil setelah penyuluhan menunjukkan perbedaan. Hasil posttest yang didapatkan menggambarkan bahwa mahasiswa memiliki pengetahuan yang berbeda atau meningkat tentang penggunaan Alat Pelindung Telinga dari bahaya kebisingan saat menggerinda.

\section{Deskripsi Variabel Sikap Mahasiswa}

Sikap mahasiswa terkait penggunaan Alat Pelindung Telinga dari bahaya kebisingan saat menggerinda dapat dideskripsikan dari gambar 3 dan gambar 4. Pretest kuesioner sikap yang diisi 17 mahasiswa menunjukkan data dengan klasifikasi kurang baik sebanyak 14 atau $82 \%$ mahasiswa dan sebanyak 3 (tiga) atau $18 \%$ mahasiswa memiliki sikap cukup baik. Penyuluhan yang dilakukan menghasilkan data posttest mahasiswa memiliki sikap cukup baik.

Sikap 17 mahasiswa sebagai responden yang cukup baik setelah dilakukan penyuluhan menunjukkan bahwa mahasiswa dapat bersikap dengan cukup baik apabila telah diberikan pemahaman yang jelas terkait penggunaan Alat Pelindung Telinga dari bahaya kebisingan saat menggerinda di Ruang Pengelasan Universitas Negeri Malang.

Sikap merupakan suatu bentuk evaluasi atau reaksi perasaan (Azwar, 2011:5). Reaksi perasaan yang dituangkan oleh mahasiswa terwujud dalam jawaban sangat setuju, setuju, tidak setuju, atau sangat tidak setuju. Sikap mahasiswa menunjukkan peningkatan yang signifikan. 
Penyuluhan yang dilakukan mampu membedakan sikap mahasiswa sebelum dan sesudah mengerti tentang materi penggunaan Alat Pelindung Telinga saat menggerinda.

Sikap merupakan salah satu presdiposisi tindakan (Notoadmodjo, 2010:54). Sikap mahasiswa yang cukup baik dalam memahami penggunaan Alat Pelindung Telinga

dari bahaya kebisingan saat menggerinda dapat dijadikan indikator untuk mengamati tindakan mahasiswa dalam menggunakan Alat Pelindung Telinga saat menggerinda.

\section{Deskripsi Variabel Tindakan Mahasiswa}

Observasi tindakan yang dilakukan kepada 17 mahasiswa sebagai responden pada saat pretest menunjukkan hanya ada satu orang mahasiswa yang menggunakan Alat Pelindung Telinga berupa Welding Helmet. Sedangkan 16 mahasiswa pada saat pretest menunjukkan

tindakan kurang tepat saat menggerinda. Tindakan yang dimaksud adalah tidak menggunakan Alat Pelindung Telinga. Data posttest yang didapatkan setelah penyuluhan yakni sebanyak 16 atau 94\% mahasiswa melakukan tindakan tepat yakni menggunakan Alat Pelindung Telinga saat menggerinda dan seorang lainnya atau $6 \%$ mahasiswa masih melakukan tindakan kurang tepat.

Tindakan merupakan salah satu bentuk respon terbuka yang dilakukan mahasiswa terhadap stimulus berupa penyuluhan yang dilakukan. Respon terbuka tersebut diwujudkan dengan menggunakan Alat Pelindung Telinga baik earmuff, earplug, maupun welding helmet saat menggerinda. Tindakan mahasiswa untuk melindungi telinga dari bahaya kebisingan yaitu penyakit akibat kerja Noise Induced Hearing Loss

merupakan indikator bahwa penyuluhan dapat dijadikan cara untuk promosi kesehatan seperti yang World Health Organization terangkan.

Peraturan Menteri Tenaga

Kerja dan Transmigrasi Republik Indonesia Nomor 08 Tahun 2010 tentang Alat Pelindung Telinga menjelaskan bahwa Alat Pelindung Telinga merupakan salah satu alat pelindung yang diperlukan untuk melindungi telinga dari kebisingan dan tekanan. National Institute of Occupational Safety and Health juga menguatkan penggunaan Alat Pelindung Telinga perlu dilakukan untuk mencegah penyakit akibat kerja yaitu Noise Induced Hearing Loss sejak dini. Kesadaran mahasiswa dalam menerapkannya masih kurang. Penyuluhan yang dilakukan dengan tujuan penerangan informasi sejelasjelasnya dapat disimpulkan mampu mempengaruhi pengetahuan, sikap, dan tindakan mahasiswa terkait penggunaan Alat Pelindung Telinga

dari bahaya kebisingan saat menggerinda di Ruang Pengelasan Universitas Negeri Malang.

Ruang Pengelasan Universitas Negeri Malang sebagai lokasi

penelitian menyediakan Alat Pelindung Telinga yang dimaksud yaitu earmuff, earplug, dan welding helmet. Setelah penyuluhan dilakukan pada minggu kedua praktikum pengelasan, mahasiswa membawa earplug yang dimiliki secara individu dan dipakai saat praktikum minggu ketiga dan peneliti mengambil data posttest tindakan mahasiswa menggunakan Alat Pelindung Telinga dari bahaya kebisingan saat menggerinda di Ruang Pengelasan Universitas Negeri Malang. 
Alat Pelindung Telinga yang dapat digunakan dan tersedia di Ruang Pengelasan Universitas Negeri Malang berupa earplug, earmuff, dan welding helmet telah sesuai dengan Peraturan Menteri Tenaga Kerja Republik Indonesia Nomor 08 Tahun 2010 tentang Alat Pelindung Diri serta sesuai dengan aturan American

Welding Society. Peneliti menggambarkan bahwa kesadaran mahasiswa dalam bertindak tepat menggunakan Alat Pelindung Telinga dari bahaya kebisingan saat menggerinda di Ruang Pengelasan Universitas Negeri Malang telah sesuai dengan ketentuan yang telah diatur.

Penelitian sebelumnya yang bertujuan untuk mengetahui pengaruh penyuluhan terhadap pengetahuan, sikap, dan tindakan petani paprika terkait penggunaan Alat Pelindung Diri dari bahaya pestisida telah dilakukan oleh Afrianto pada tahun 2013 di Desa Kumbo Kabupaten

Pasuruan. Hasil penelitian menyimpulkan bahwa ada pengaruh penyuluhan terhadap pengetahuan, sikap, dan tindakan petani paprika dengan membandingkan pretest dan posttest yang diberikan kepada petani paprika. Pengetahuan sebagai variabel pertama yang diukur dalam penelitian ini merupakan dasar seseorang dalam berperilaku. Seseorang yang memiliki pengetahuan berbanding lurus dengan motivasi untuk berperilaku sehat (Sriopas, dkk (2017:61).

Kourorian Z, dkk (2014:180)

menyimpulkan bahwa dalam meningkatkan pengetahuan, sikap, dan tindakan individu diperlukan pemberian intervensi yang positif. Intervensi yang dimaksud dapat berupa penyuluhan kesehatan sebagai salah satu bentuk langkah promotif dan preventif. Intervensi dalam kesehatan dapat dilakukan dengan memberikan beberapa bentuk pendidikan kesehatan. Pendidikan tentang kesehatan dapat diberikan secara formal dan non formal dengan salah satu implementasinya adalah memberikan penyuluhan di institusi pendidikan (B. K. Tones, 2014:22). Penyuluhan sebagai salah satu upaya pendidikan kesehatan dapat dilakukan dengan menganalisis latar belakang sasaran. Latar belakang yang dimaksud adalah keadaan yang dipandang kurang dan atau tidak sehat baik dikarenakan bahaya lingkungan, manusia, dan atau makhluk lainnya.

Pengamatan yang dilakukan sebelum dan sesudah penyuluhan kepada 17 mahasiswa sebagai responden menunjukkan perbedaan yang signifikan. Hal tersebut dikarenakan penyuluhan dilakukan dengan menerangkan informasi kesehatan sebagai upaya promosi kesehatan untuk mencegah penyakit akibat kerja kepada mahasiswa. Perbedaan pengetahuan, sikap, dan tindakan mahasiswa sebelum dan sesudah penyuluhan menunjukkan bahwa ada pengaruh penyuluhan terhadap pengetahuan, sikap, dan

tindakan mahasiswa terkait penggunaan Alat Pelindung Telinga

dari bahaya kebisingan saat menggerinda di Ruang Pengelasan Universitas Negeri Malang.

\section{KESIMPULAN}

Hasil deskripsi data, pengujian hipotesis, dan pembahasan yang dilakukan menghasilkan kesimpulan sebagai berikut:

1. Ada perbedaan pemahaman pengetahuan mahasiswa terkait penggunaan Alat Pelindung Telinga dari bahaya kebisingan saat menggerinda di Ruang Pengelasan Universitas Negeri 
Malang sebelum dan sesudah penyuluhan.

2. Ada perbedaan sikap mahasiswa terkait penggunaan Alat Pelindung Telinga dari bahaya kebisingan saat menggerinda di Ruang Pengelasan Universitas Negeri Malang sebelum dan sesudah penyuluhan.

3. Ada perbedaan tindakan mahasiswa menggunakan Alat Pelindung Telinga dari bahaya kebisingan saat menggerinda di Ruang Pengelasan Universitas Negeri Malang sebelum dan sesudah penyuluhan.

\section{SARAN}

Saran-saran yang peneliti berikan dapat dijadikan sebagai bahan pertimbangan untuk beberapa pihak yang menggunakan penelitian ini sebagai referensi. Saran yang dikemukakan oleh peneliti sebagai berikut:

1. Bagi Penelitian Selanjutnya

Pengembanganvariabel

penelitian baik variabel bebas maupun variabel terikat. Variabel bebas dapat dikembangkan menjadi pelatihan dan pendidikan. Variabel terikat dapat dikembangkan dengan perilaku dan kebiasaan.

2. Bagi Jurusan Ilmu Kesehatan Masyarakat

Artikel dan jurnal penelitian terdahulu dan relevan perlu diperbarui sehingga dapat menjadikan penelitian selanjutnya kaya akan kajian penelitian terdahulu dan memiliki kekhasan penelitian dengan penelitian lainnya. Referensi jurusan Ilmu

Kesehatan Masyarakat pada umumnya dan pilar Keselamatan dan Kesehatan Kerja (K3) pada khususnya dapat bertambah tentang penggunaan Alat Pelindung Diri dan promosi kesehatan.
3. Bagi Mahasiswa Jurusan Teknik Mesin

Mahasiswa Teknik Mesin yang menempuh Praktikum Pengelasan di Ruang Pengelasan

Universitas Negeri Malang disarankan untuk selalu menggunakan Alat Pelindung Telinga yang tersedia yaitu earplug, earmuff, dan atau welding helmet saat menggerinda untuk melindungi diri dari bahaya kebisingan.

\section{DAFTAR RUJUKAN}

Afrianto, D. 2013. Pengaruh Penyuluhan terhadap Pengetahuan, Sikap, dan Tindakan Petani Paprika di Desa Kumbo Pasuruan terkait Penggunaan Alat Pelindung Diri (APD) dari Bahaya Pestisida Tahun 2014. Skripsi diterbitkan. Jakarta: Fakultas

Kedokteran dan Ilmu Kesehatan UIN Syarif Hidayatullah.

Amanah, S. 2007. Makna Penyuluhan dan Transformasi Manusia. Jurnal Penyuluhan, 3(1): 6367.

American Welding Society. 2013. Safety and Health Fact Sheet 6: Mechanical Hazards, (Online), (http://www.aws.org/), diakses pada 8 April 2017.

Arikunto, S. 2010. Prosedur Penelitian. Jakarta: Rineka Cipta.

Azwar,S. 2011. Sikap Manusia: Teori dan Pengukurannya. Yogyakarta: Pustaka Pelajar.

Barman, P. \& Singh, B. Int. J. 2017. Influence of Tyre Buffings and Cement on Strength Behaviour of Soli-Fly Ash Mixes. International Journal 
of Geosynthetics and Ground

Enginerring, 3 (10): 1-3.

Centers of Disease Control and

Prevention:The National

Institute of Occupational

Safety and Health. 2016.

Noise and Hearing Loss

Prevention,

(Online),

(https://www.cdc.gov/niosh/to

pics/noise/), diakses pada 2

September 2016.

Christy, C. C. 2010. Laporan Khusus:

Dampak Faktor Bahaya

Kebisingan terhadap Tenaga

Kerja di Bagian Unit Power

Plant Pusat Pendidikan dan

Pelatihan Migas Bumi Cepu,

Blora, Jawa Tengah.

Surakarta: $\quad$ Fakultas

Kedokteran Universitas

Sebelas Maret Surakarta.

Expedisi Murah. 4 September 2015.

Pengertian Mesin Gerinda sebagai Alat Potong Besi dan

Stainless. General Discussion,

(Online),

(https://www.bersosial.com/th

reads/pengertian-mesin-

gerinda-sebagai-alat-potong-

besi-dan-stainless.26757)

diakses 20 November 2016.

Kustono, D. 2016. Ilmu Perilaku sebagai Strategi Mencegah Kecelakaan Kerja.Malang:

Fakultas Teknik Universitas Negeri Malang.

Kepala Pusat Promosi Kesehatan. 2011. Promosi Kesehatan di

Daerah Bermasalah

Kesehatan: Panduan bagi

Petugas Kesehatan di

Puskesmas. Jakarta:

Kementerian Kesehatan

Republik Indonesia.

Kementerian Tenaga Kerja dan

Transmigrasi Republik

Indonesia. 2010. Peraturan

Menteri Tenaga Kerja dan
Transmigrasi Nomor 08

Tahun 2010 tentang Alat

Pelindung Diri. Jakarta:

Kementerian Tenaga Kerja dan Transmigrasi Republik Indonesia.

Kementerian Tenaga Kerja dan

Transmigrasi Republik

Indonesia. 2011. Peraturan

Menteri Tenaga Kerja dan

Transmigrasi Nomor 13

Tahun 2011 tentang Nilai

Ambang Batas Faktor Fisika

dan Faktor Kimia di Tempat

Kerja. Jakarta: Kementerian

Tenaga Kerja dan

Transmigrasi Republik

Indonesia.

Kirchner, D B et al. 2012.

Occupational Noise Induced

Hearing Loss. American

Journal of Occupational and

Environmental Medicine,54: 106-108.

Kourorian et al. 2014. The Effect of

Knowledge, Attitude, and

Practice on the Function of

Thalassemic Patients. Iranian

Journal of Blood and Cancer, 6 (4): 177-181.

Kyoo Sang Kim. 2010. Occupational Hearing Loss in Korea. Journal of Korean Medical Science, 30 (2): 33-45.

Laird, I. 2012. The Epidemiology and Prevention of NIHL in New Zeeland. Wellington: Massey University.

Marji. 2013. K3 (Kesehatan dan Keselamatan Kerja) seri Kebisingan. Malang: Gunung Samudera.

Marzuki, M. S. 2009. DimensiDimensi Pendidikan

Nonformal (M. Guntur

Waseso, Ed). Malang:

Fakultas Ilmu Pendidikan

Universitas Negeri Malang. 
Mubarak, W. I., dkk. 2007. Promosi Kesehatan: Sebuah Pengantar Proses Belajar Mengajar dalam Pendidikan. Yogyakarta: Graha Ilmu.

Muninjaya. 2004. Manajemen Kesehatan. Jakarta: EGC.

Mustafa, Z. 2009. Mengurai Variabel Hingga Instrumentasi. Yogyakarta: Graha Ilmu.

Notoatmodjo, S. 2010. Promosi Kesehatan: Teori dan Aplikasi. Jakarta: Rineka Cipta.

Notoatmodjo, S. 2012. Metodologi Penelitian Kesehatan. Jakarta: Rineka Cipta.

Pingili, R. R. 2012. Study of Safety in Welding Process. International Journal of Applied Engineering Research, 7 (11): 1-4.

Prasetyo, L. A. 2015. Hubungan Kebisingan Bengkel Las Terhadap Noise Induced Hearing Loss pada Pekerja Las di Kecamatan Purwareja Klampok. Tesis diterbitkan. Semarang: Fakultas Kedokteran Universitas Islam Sultan Agung Semarang

Salawati, L. 2013. Noise Induced Hearing Loss (NIHL). Jurnal Kedokteran Syiah Kuala, 13(1): 45-49.

Sarjono, H. dan Julianita, W. 2011. SPSS VS LISRAEL: Sebuah Pengantar Aplikasi untuk Riset. Jakarta: Salemba.

Sastrosupadi, A. 2000. Rancangan Percobaan Praktis Bidang Pertanian. Yogyakarta: Kanisius.

Solichin, dkk. 2014. Dasar-Dasar Keselamatan dan Kesehatan Kerja. Malang: Universitas Negeri Malang.
Sriopas, A., dkk. 2017. Occupational Noise Induced Hearing Loss in Auto Part Factory Workers in Welding Units in Thailand. Journal of Occupational Health, 59: 55-62.

Swarjana, I. K. 2015. Metodologi Penelitian Kesehatan:

Tuntutan Praktis Pembuatan Proposal Penelitian untuk Keperawatan, Kebidanan, dan Profesi Bidang Kesehatan Lainnya. Yogyakarta: Andi.

Sugiyono. 2010. Metode Penelitian Kuantitatif, Kualitatif, dan $R \& D$. Bandung: Alfabeta

Sugiyono. 2013. Metode Penelitian Pendidikan. Bandung: Alfabeta.

Syarifuddin, A. 2015. Pengaruh Penerapan Kesehatan dan Keselamatan Kerja (K3) terhadap Keamanan Kegiatan Praktik Listrik Otomotif dan Kenyamanan Belajar Siswa Kelas XI Program Studi Keahlian Otomotif SMK di Malang.Skripsi diterbitkan. Malang: Fakultas Teknik Universitas Negeri Malang.

Tim Penyusun Kamus Pusat Bahasa. 2002. Kamus Besar Bahasa Indonesia. Jakarta: Balai Pustaka.

Tones, B. K. 2014. Training Needs for Health Education. Journal of The Institute of Health Education, 15 (1): 22.

Tim Tetap Penyusun Pedoman Penulisan Karya Ilmiah. 2010. Pedoman Penulisan Karya Ilmiah. Malang: UM PRESS.

United States Department of Labor: Occupational Safety and Health Administration. General Requirements: Welding, Cutting, and Brazzing, (Online), 
(http://www.osha.gov),

diakses pada 2 September 2016.

Z'gambo, J. 2015. Occupational Hazards and Use of Personal Protective Equipmentamong Small Scale Welders in Lusaka Zambia. Tesis diterbitkan. Norway: University of Bergen. 